\title{
PEMAKAMAN MASA DEPAN RAMAH LINGKUNGAN DI CISAUK
}

\author{
Gregorius Agung Dwinurcahyo ${ }^{1)}$, Tony Winata ${ }^{2)}$ \\ 1)Program Studi S1 Arsitektur, Fakultas Teknik, Universitas Tarumanagara, \\ gregorius.315150164@stu.untar.ac.id \\ 2)Program Studi S1 Arsitektur, Fakultas Teknik, Universitas Tarumanagara, tonywinata@ft.untar.ac.id
}

Masuk: 04-07-2021, revisi: 30-07-2021, diterima untuk diterbitkan: 23-10-2021

\begin{abstract}
Abstrak
Manusia tidak lepas dari 2 kejadian penting dalam kehidupannya yaitu kelahiran dan kematian, pada akhirnya semua makhluk hidup akan meninggal dan lahir pada waktunya masing-masing yang akan menjadi masalah adalah tingginya tingkat pertumbuhan penduduk di kota-kota besar yang tidak diselaraskan dengan penyediaan lahan pemakaman. Lahan untuk pemakaman yang terus dibutuhkan setiap saat, tetapi lahan kosong yang tidak mungkin bertambah, mengakibatkan semakin tingginya kekurangan lahan pemakaman yang terjadi di masyarakat. Eco-Cemetery for the Future dengan memasukan ekologi ke dalam desain, bertujuan untuk menjadikan pemakaman sebagai ruang terbuka untuk sarana umum yang aman dan nyaman, pengendalian dan pemanfaatan lahan yang dapat dilakukan secara terencana, terarah, efektif dan efisien, merancang pemakaman yang ramah lingkungan dengan dampak negatif yang kecil terhadap lingkungan, dan kehidupan manusia di masa depan.
\end{abstract}

\section{Kata kunci: Berkelanjutan; Pemakaman; Ramah Lingkungan; Ruang Terbuka}

\begin{abstract}
This Humans cannot be separated from 2 important events in their lives, namely birth and death, in the end all living things will die and be born at their respective times. The problem is the high rate of population growth in big cities which is not aligned with the provision of burial grounds. Land for burial is needed all the time, but the vacant land is impossible to increase, resulting in the increasing shortage of burial land that occurs in the community. Eco-Cemetery for the Future by incorporating ecology into the design, aims to make the cemetery an open space for safe and comfortable public facilities, control and use of land that can be carried out in a planned, directed, effective and efficient manner, designing an environmentally friendly cemetery by small negative impact on the environment, and human life in the future.
\end{abstract}

\section{Keywords: Cemetery; Environmentally friendly; Open Space; Sustainable}

\section{PENDAHULUAN} Latar Belakang

Perlu kita ketahui bahwa semua makhluk hidup di dunia ini membutuhkan tempat tinggal berlaku untuk semuanya, baik yang masih hidup maupun yang sudah meninggal, serta bagi hewan dan juga tumbuhan. Ibaratnya seperti masuk ke dalam istilah ekologi dan beyond ecology, semua harus hidup berdampingan, hidup secara bersamaan, dan tidak ada yang mendominasi dibandingkan satu sama yang lainnya. Ekologi itu sendiri yang berasal dari kata Oikos + Logi yang memiliki arti ilmu tentang rumah (oikos). Rumah yang dimaksud bukan secara harfiah rumah tetapi memiliki tempat di dalam ekosistem tersebut. Manusia tidak lepas dari 2 kejadian penting dalam kehidupannya yaitu kelahiran dan kematian. Pada akhirnya semua makhluk hidup akan meninggal pada waktunya masing-masing demikian pula ada juga kelahiran yang akan menjadi masalah apabila reproduksi manusia tidak dapat dikendalikan sehingga bisa menimbulkan peningkatan penduduk yang tinggi. Serupa dengan kematian, jika 
tingkat kematian tinggi maka lahan untuk pemakaman akan menjadi terbatas. Pada kenyataannya, tingkat kematian akan berjalan meningkat sejajar dengan meningkatnya jumlah kelahiran tetapi lahan yang tersedia semakin terbatas untuk digunakan sebagai tempat tinggal, bekerja, hingga ke bidang pertanian, tetapi lahan yang sudah terbatas dan tidak bisa bertambah itu sedikit yang diperuntukan untuk pemakaman. Dengan tidak bertambahnya jumlah pemakaman dari tahun 2011 hingga data terakhir pada tahun 2018, dengan jumlah pemakaman 242 dan rasio dengan jumlah penduduk di angka $0.013 \%$ sedangkan pertumbuhan penduduk dari tahun 2010 hingga tahun 2018 di angka 2.46 dengan jumlah total 2.185.305, membuat Kota Tangerang diambang kekurangan lahan untuk pemakaman di masa yang akan datang. RTH kota Tangerang sebagaimana dimaksud dalam Pasal 32 huruf $b$ terdiri atas ruang terbuka hijau publik dan ruang terbuka hijau privat. Persentase luas keseluruhan RTH direncanakan sekurang-kurangnya ditetapkan 30\% dari luas wilayah Kota Tangerang yang terdiri atas $20 \%$ RTH publik dilakukan secara bertahap dan $10 \%$ RTH privat (Walikota Tangerang, 2012).

Fasilitas pemakaman merupakan suatu hal yang mutlak adanya dalam melayani masyarakat, karena fasilitas pemakaman merupakan hal yang harus disediakan sama seperti halnya fasilitas perkantoran, perumahan, dan pasar hingga kesehatan, yang semuanya memerlukan lahan sehingga dalam penyediaannya mengalami persaingan yang ketat dalam penggunaan lahan. Kebiasaan berziarah ke pemakaman serta keyakinan meminta pertolongan terhadap roh jenazah oleh orang yang masih hidup adalah hal yang lazim dianut dan dilaksanakan oleh sebagian masyarakat indonesia, berlaku juga untuk masyarakat di Kota Tangerang, hal ini sudah menjadi sistem nilai budaya yang berakar sehingga efisiensi lahan kuburan dengan sistem penguburan susun atau menggunakan kembali kuburan yang tidak terawat menjadi sulit dilaksanakan. Masalah lain adalah kurangnya pengolahan lahan dan efesiensi lahan sehingga penggunaan untuk ruang terbuka hijau juga berkurang. Kurangnya kesadaran untuk mengurangi penggunaan energi juga rendah, yang seharusnya bisa dikurangi dan digantikan dengan energi terbaharukan. Maka dari itu agar mencapai pengelolaan dan perancangan pemakaman yang hijau dengan prinsip ekologi perlu adanya kajian dan penelitian lebih dalam, dan penerapannya di kehidupan nyata.

\section{Rumusan Permasalahan}

Berdasarkan latar belakang diatas diketahui terdapat masalah yang terjadi, yaitu terdapat isu lahan pemakaman yang terbatas karena terus dibutuhkan setiap saat, tetapi lahan kosong yang tidak mungkin bertambah, Pemakaman yang ada pada saat ini dapat dibilang kurang asri, teratur, aman, nyaman, dan tidak ramah lingkungan. Masalah ini tidak dianggap penting oleh masyarakat sehingga belum diterapkannya solusi yang terbaik. Bagaimana arsitek menerapkan solusi terhadap permasalahan pemakaman yang ada?

\section{Tujuan}

Menjadikan pemakaman sebagai ruang terbuka untuk sarana umum yang aman dan nyaman. Untuk menambah refrensi dan keilmuan di dibidang serupa; Merancang pemakaman yang ramah lingkungan untuk mencapai target yang ditetapkan pemerintah pusat untuk penyediaan pemakaman dan ruang terbuka hijau; Memberikan wadah untuk masyarakat sekitar memilliki ruang terbuka hijau yang ramah lingkungan, aman dan nyaman untuk mereka gunakan seharihari.

\section{KAJIAN LITERATUR EKOLOGI DAN PEMAKAMAN}

\section{Ekologi}

Istilah ekologi diciptakan oleh ahli zoologi Jerman, Ernst Haeckel, pada tahun 1866 untuk menggambarkan ekonomi dari bentuk kehidupan. Ekologi dapat diartikan sebagai sebuah 
rumah/ oikos yang melakukan dan mendapatkan hasil dari transaksi serta negosiasi terhadap kondisi lingkungan yang dihadapinya. Dalam catatan dari Stanford Encyclopedia of Philosophy dijelaskan bahwa ada dua masalah penting ketika dihadapkan dalam diskusi ekologi, yaitu Masalah kompleksitas, membicarakan masalah ekologi dihadapkan bukan hanya pada masalah yang rumit tetapi memiliki kompleksitas tinggi. Kondisi rumit dan kompleks ini disebabkan karena menyangkut tentang hubungan antara manusia dengan kondisi alam yang memiliki kedinamisan dalam perubahannya); Masalah keunikan yaitu sistem ekologi dianggap unik baik karena merupakan entitas historis yang bergantung, dan secara struktural karena kompleksitasnya. 1 Kompleksitas dan Keunikan dari sebuah kondisi ekosistem menjadi kata kunci dalam menghasilkan kajian keruangan baru bagi bumi ini.

\section{Arsitektur Ekologi}

Indikator - indikator yang harus diperhatikan dalam arsitektur ekologi yaitu optimalisasi sumber daya alam dan buatan, pemanfaatan sumber daya alam, penggunaan material yang tahan lama, penggunaan bahan yang dipulihkan, dan bahannya dapat digunakan kembali. Tingkat penggunaan sumber daya yang digunakan seperti energi yang dikonsumsi dalam produksi bahan, energi yang dikonsumsi dalam mengangkut material, energi yang dikonsumsi dalam mengangkut tenaga kerja, energi yang dikonsumsi dalam proses pembangunan gedung, dan energi yang dikonsumsi oleh gedung sepanjang hidupnya. Promosi sumber energi alam seperti tingkat teknologi energi matahari yang digunakan, tingkat teknologi energi panas bumi yang digunakan, dan tingkat penggunaan teknologi energi terbarukan berdasarkan ekosistem alam. Pengurangan limbah dan emisi yang dihasilkan dalam produksi bahan bangunan, dalam proses konstruksi dan dalam pemeliharaan gedung Limbah dan emisi yang dihasilkan dalam pembongkaran bangunan. Peningkatan kualitas hidup penghuni gedung seperti emisi berbahaya bagi ekosistem alam, emisi berbahaya bagi kesehatan manusia, jumlah penyakit penghuni gedung, dan kepuasan dan kesejahteraan penghuni gedung.

Mengurangi perawatan dan biaya bangunan seperti tingkat konsistensi antara keawetan bahan dan siklus hidup fungsionalnya, fungsi komponen, sumber Daya Harian dikonsumsi oleh gedung, energi yang dikonsumsi oleh peralatan teknologi gedung, energi yang dikonsumsi dalam aksesibilitas ke gedung, energi sisa yang dikonsumsi oleh gedung saat tidak digunakan. Level perawatan di gedung, tingkat kebutuhan untuk pengolahan emisi dan limbah yang dihasilkan oleh gedung, biaya ekonomi konstruksi dan lingkungan social-ekonomi. Ekologi dapat disimpulkan sebuah rumah/oikos yang melakukan dan mendapatkan hasil dari transaksi serta negosiasi terhadap kondisi lingkungan yang dihadapinya. Sedangkan beyond ecology atau melampaui ekologi adalah sebuah kondisi ekosistem dengan formasi sosialnya yang mengalami kondisi kecepatan dan percepatan. Pada titik ini, kecepatan menjadi jantung dunia keseharian dan ekosistem di sekitar kita mengalami "pemadatan waktu" sebagai konsekuensi dari percepatan kehidupan.

\section{Pemakaman}

Sejak dahulu umat manusia sudah mulai untuk meninggalkan rekaman dan jejak hidup pada peradabannya. Sehingga manusia mulai memikirkan hal yang dianggap sebagai bentuk rekaman ketika manusia tersebut mengalami kematian dan pemakaman merupakan salah satu bentuk rekaman yang baik. Pengetahuan bahwa setiap makhluk hidup akan mati mengarahkan hasrat manusia untuk mengingatkan orang lain tentang kehadirannya dengan cara membangun sebuah monumen, mendirikan arsitektur pemakaman, bahkan membuat orang yang ditinggalkan memperingati hari kematiannya (Steven Curl, 2002). Tempat pemakaman di Indonesia dibedakan menjadi beberapa jenis, yaitu Tempat Pemakaman Umum (TPU) yang ditujukan untuk masyarakat umum yang penggolongannya dibedakan berdasarkan agama yang dianut. Setiap agama memiliki aturan tersendiri untuk mengatur lahan pemakaman. 
Pemanfaatannya sebagai lahan terbuka hijau tidak sama dalam masing-masing pemakaman. Selain itu, terdapat juga Tempat Pemakaman Khusus (TPK) yang biasanya berupa Taman Makam Pahlawan. Setiap jenis makam tersebut memiliki kelebihan dan kekurangan untuk dimanfaatkan sebagai ruang terbuka hijau sangat dibutuhkan proses perencanaan pembangunan kota yang berwawasan lingkungan di seluruh wilayah perkotaan di Indonesia. Dengan pemanfaatan ruang terbuka yang selama ini belum atau kurang dimanfaatkan harus lebih dimaksimalkan lagi pemanfaatannya, seperti tempat pemakaman. Tempat pemakaman merupakan salah satu bentuk RTH kota yang belum efektif pemanfaatannya sebagai RTH.

Hal ini selaras dengan Instruksi Menteri Dalam Negeri Nomor 14 Tahun 1988 tentang Penataan Ruang Terbuka Hijau di Wilayah Perkotaan dan diperbaharui dalam Peraturan Menteri Dalam Negeri Nomor 1 Tahun 2007 tentang Penataan Ruang Terbuka Hijau Kawasan Perkotaan, "Keberadaan TPU harus ada dan tetap dipertahankan di tengah-tengah kehidupan kota metropolitan. Sebab menurut Eko Budhiharjo, pemakaman merupakan komponen utama dalam siklus kehidupan kota, condition sine qua non, syarat mutlak yang tidak bisa ditawartawar "selain itu, tempat pemakaman harus dilihat sebagai aset, potensi, dan investasi kota jangka panjang, sebagai tujuan ekowisata kota dan layanan kremasi yang sehat dan ramah lingkungan (nilai ekonomi), makam bersejarah orang-orang terkenal dan ruang spiritual warga kota, serta taman konservasi kota, yang terbukti mampu mendanai keberlanjutan (Joga dan Antar, 2007).

\section{Tempat Pemakaman Umum}

Berdasarkan Peraturan Pemerintah Nomor 9 Tahun 1987 tentang penyediaan dan penggunaan tanah untuk keperluan tempat pemakaman. Pengelolaan tanah tempat pemakaman di Indonesia dewasa ini kenyataannya dapat dibedakan dalam beberapa macam, yaitu

\section{Tempat Pemakaman Umum}

Tempat Pemakaman Umum dilaksanakan oleh Pemerintah Daerah atau Pemerintah Desa, dimana area tanah tersebut disediakan untuk pemakaman jenazah bagi seluruh anggota masyarakat dengan tidak membedakan agama, bangsa atau kewarganegaraannya.

\section{Tempat Pemakaman Bukan Umum}

Tempat pemakaman bukan umum yang juga disebut tempat pemakaman swasta pengelolaannya dilakukan oleh swasta dan hanya dimungkinkan oleh suatu badan yang bergerak di bidang sosial atau keagamaan dengan memperhatikan ketentuan-ketentuan yang telah digariskan oleh pemerintah daerah.

\section{Tempat Pemakaman Khusus}

Di samping Tempat Pemakaman Umum dan Tempat Pemakaman Bukan Umum tersebut di atas, terdapat tempat-tempat pemakaman yang mempunyai nilai sejarah dan budaya seperti pemakaman para Wali Songo, Raja-raja (Pemakaman Imegiri), tempat pemakaman para pahlawan dan pejuang bangsa serta tempat pemakaman perang Belanda di tujuh kota sesuai dengan Keputusan Presiden Nomor 30 Tahun 1971.

\section{Krematorium}

Tempat pembakaran jenazah atau kerangka jenazah yang pelaksanaannya dilakukan Pemerintah Daerah, masyarakat maupun badan yang bergerak di bidang sosial atau keagamaan dengan memperhatikan persyaratan yang ditetapkan oleh pemerintah daerah.

Tempat Penyimpanan Jenazah. Menurut adat yang masih berlaku di berbagai tempat di Indonesia, dikenal beberapa masyarakat hukum adat yang tidak mengubur jenazah di dalam tanah melainkan menyimpan jenazah jenazah di dalam lubang-lubang atau gua-gua ataupun 
menempatkan jenazah di tempat-tempat yang terbuka, yang karena keadaan alamnya mempunyai sifat-sifat khusus dibandingkan dengan tempat lain.

Berdasarkan pengertian tersebut, penelitian ini dibatasi hanya tempat pemakaman umum yang ada di Kota Tangerang, yaitu TPU Kristen (TPU Kristen merupakan tempat pemakaman umum yang digunakan untuk memakamkan orang-orang yang pada saat meninggal dunia beragama Kristen); TPU Islam/Muslim (TPU Islam merupakan tempat pemakaman umum yang digunakan untuk memakamkan orang-orang yang pada saat meninggal dunia beragama Islam); TPU Tionghoa (TPU Tionghoa merupakan tempat pemakaman umum yang digunakan untuk memakamkan orang-orang yang pada saat meninggal dunia beragama Tionghoa).

Berikut merupakan bahan-bahan dari alam yang diperlukan setiap tahun di AS untuk mengubur lebih dari 2,5 juta orang di 22.500 pemakaman yang berdampak pada lingkungan, terdiri dari (menurut jurnal Aysel Uslu : "Ecological Concerns Over Cemeteries 2009", hal: 1509) : Terdiri dari, 30 juta papan $\left(70.000 \mathrm{~m}^{3}\right.$ ) dari peti kayu, 90.272 ton kubah (untuk peti mati), 14.000 ton kubah (untuk kuburan), 2.700 ton tembaga dan perunggu (untuk peti mati), 1.636 .000 beton (untuk kuburan), 872,060 galon ( 1 galon $=3,78$ It.) Cairan pembalseman, yang paling umum termasuk formaldehida. Tempat pemakaman di Indonesia dibedakan menjadi beberapa jenis, yaitu: Tempat Pemakaman Umum (TPU) yang ditujukan untuk masyarakat umum yang penggolongannya dibedakan berdasarkan agama yang dianut. Setiap agama memiliki aturan tersendiri untuk mengatur lahan pemakaman. Pemanfaatannya sebagai lahan terbuka hijau tidak sama dalam masing-masing pemakaman. Selain itu, terdapat juga Tempat Pemakaman Khusus (TPK).

\section{Ruang Terbuka Hijau}

Pengertian dan Fungsi RTH Istilah RTH dikemukakan dalam Instruksi Menteri Dalam Negeri (Inmendagri) Nomor 14 Tahun 1988 tentang Penataan Ruang Terbuka Hijau di wilayah perkotaan dan diperbaharui dalam Peraturan Menteri Dalam Negeri Nomor 1 Tahun 2007 tentang Penataan Ruang Terbuka Hijau Kawasan Perkotaan. Dijelaskan dalam Inmendagri ini bahwa pengertian ruang terbuka adalah ruang ruang dalam kota atau wilayah lain yang lebih luas, baik dalam bentuk area/ kawasan maupun dalam bentuk memanjang/ jalur dimana dalam penggunaannya lebih bersifat terbuka dan pada dasarnya tanpa bangunan. RTH sendiri adalah ruang terbuka yang di dalam pemanfaatannya didominasi oleh pengisian hijau tanaman atau tumbuh-tumbuhan secara alamiah ataupun budidaya tanaman seperti lahan pertanian, pertamanan, perkebunan dan sebagainya.

\section{Rumah Abu}

Rumah abu adalah tempat penghormatan bagi orang meninggal yang telah dikremasi dan biasanya abu jenazahnya disimpan di sebuah pasu, yakni sebuah guci yang menyimpan sisa kremasi almarhum. Nama lain dari rumah abu adalah "kolumbarium", yang berasal dari bahasa Latin, columba (burung merpati) dan awalnya merujuk pada perumahan yang diperuntukkan bagi burung merpati yang disebut

\section{METODE}

\section{Metode Sustainable}

Metode perancangan yang digunakan pada proyek ini menggunakan Prinsip Desain Sustainable, permasalahan di dalam pemakaman berasal dari banyak faktor, dari faktor yang berskala besar hingga berskala kecil, dari permasalahan adat istiadat hingga permasalahan lingkungan. Masalah - masalah tersebut dapat ditemukan di pemakaman di Kota Tangerang, maka diperlukan solusi yang mengurangi dampak dari masalah tersebut. Dari teori - teori 
diatas maka munculah istilah eco-cemetery, yang berasal dari gabungan 2 kata ecology dan cemetery, yang dimaksud eco-cemetery disini adalah pemakaman yang menggunakan prinsip prinsip ekologi di dalamnya, membuat pemakaman yang lebih ramah lingkungan, dan lebih peka terhadap isu isu yang ada di dalamnya. Eco-cemetery bertujuan untuk mengakomodasi alam ke dalam pemakaman yang dikenal dengan gersang dan tidak ramah lingkungan, membuat alam memiliki tempat di dalam pemakaman tersebut agar lebih menghargai alam, dan kehidupan di dalamnya, karena diingatkan terhadap kematian yang akan menjadi ujung kehidupan itu sendiri. Taman-taman dan ekosistem yang akan berada di dalamnya juga membantu membangun suasana yang tenang dan suasana spiritual bagi pengunjung. Dalam proyek ini akan ada beberapa kegiatan yang akan difasilitasi seperti

\section{Pemakaman}

Fungsi pemakaman ini adalah untuk menciptakan alternatif pemakaman yang ramah lingkungan dengan dampak negatif yang kecil terhadap lingkungan. Pemakaman yang menyediakan tempat tidak hanya untuk manusia tetapi untuk alam, menyatu dengan program ruang terbuka hijau yang akan dirancang sebagai landscape pemakaman.

\section{Rumah Duka}

Fungsi rumah duka ini adalah untuk mewadahi khususnya para orang meninggal baik dengan cara dikubur atau dikremasi. Menyediakan tempat untuk keluarga mendoakan yang sudah meninggal sesuai adat atau kepercayaan mereka masing masing.

\section{Tempat Doa}

Fungsi ruang berdoa ini adalah untuk menyediakan tempat beribadah untuk pihak keluarga mendoakan pihak yang meninggal dengan nyaman, akan disediakan untuk berbagai adat dan kepercayaan yang ada di Kota Tangerang.

\section{Rumah Abu}

Fungsi rumah abu ini adalah untuk menyediakan fasilitas untuk yang berkehendak mau dimakamkan dengan cara diabukan, dengan fasilitas yang nyaman, ramah lingkungan dan juga lebih hemat energi. Pengunjung juga bisa menempatkan abunya untuk berziarah berdasarkan kepercayaan mereka masing masing.

\section{DISKUSI DAN HASIL}

\section{Lokasi Tapak}

Analisis Tapak Terpilih

Tapak terpilih ini terletak di Jalan Lingkar Selatan terletak di kelurahan Suradita yang berada di kecamatan Cisauk, Kota Tangerang Selatan. Sebagai kawasan yang dikenal dengan area perumahan dan ruang terbuka hijau yang banyak belum diolah. Cisauk dikenal karena menjadi daerah yang banyak dilewati orang untuk transit dan berpindah ke tempat lain oleh pengguna KRL. Tapak ini juga berdekatan dengan BSD, sungai Cisadane dan stasiun kereta Cisauk. Tapak terpilih berada di Jalan Lingkar Selatan, Kecamatan Cisauk, Kota Tangerang Selatan, dengan zonasi sebagai kelas 3 yaitu Kawasan Pemakaman. 


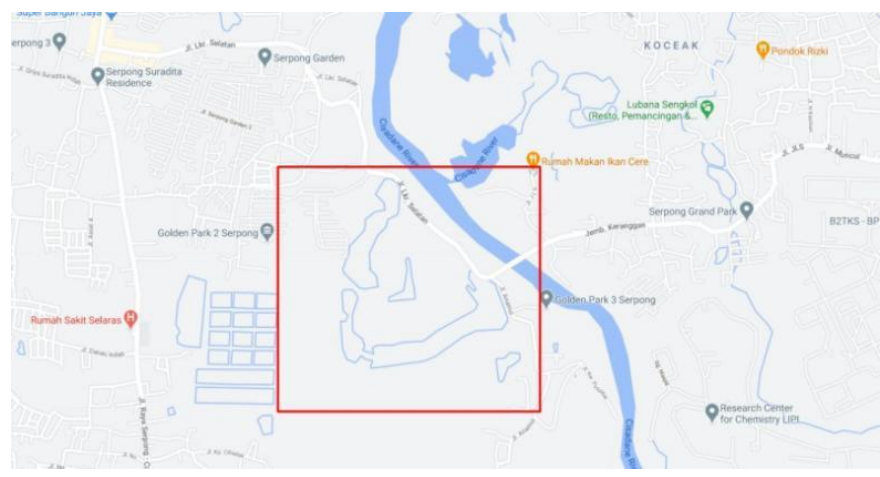

Gambar 1. Peta Tapak di Cisauk

Sumber: www.google.com/maps

\section{Aksesibilitas, Pencapaian dan Transportasi Ke Tapak}

Aksesibilitas tapak terpilih berada di dekat daerah Bumi Serpong Damai dan juga sungai Cisadane. Tetapi tidak memiliki transportasi umum, berada di Jalan Lingkar Selatan, cara mencapai tapak dengan kendaraan pribadi seperti motor dan mobil. Tapak juga cenderung banyak dilalui oleh para pejalan kaki, yang dikarenakan tapak terletak di sekitar perumahan dan dapat diakses oleh seluruh masyarakat yang menjadi tujuan proyek untuk mendatangkan masyarakat ke dalam tapak ini.

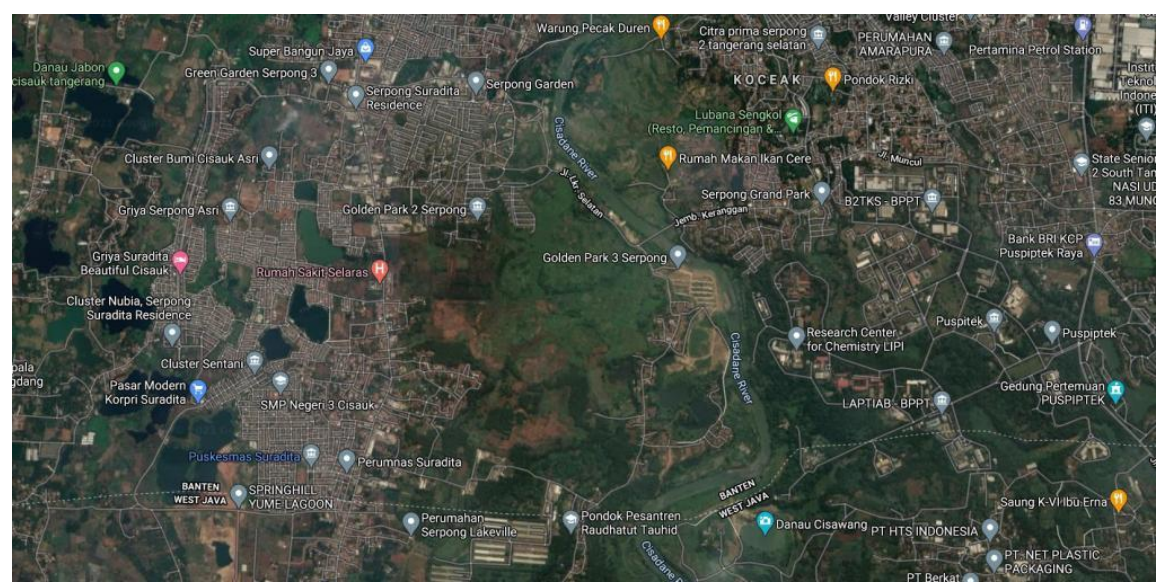

Gambar 2. Peta tapak terpilih di kawasan Cisauk, Kota Tangerang Selatan Sumber: www.google.co.id/maps

\section{Vegetasi}

Seperti yang dapat dilihat dari hasil foto satelit kawasan Cisauk, Kota Tangerang Selatan memiliki cukup banyak area hijau, sedangkan area perumahan dan ekonomi terkonsentrasi di satu area. Namun sangat disayangkan ruang terbuka hijau yang banyak tersedia secara alami tersebut tidak dapat dimanfaatkan oleh masyarakat untuk kegiatan sehari-hari secara maksimal karena kurang diolah dan dijaga. Dikhawatirkan akan adanya perluasan dari daerah BSD, area perumahan sehingga menggusur dan mengurangi ruang terbuka hijau yang terbentuk secara alami tersebut digantikan oleh lebih banyak perumahan. Oleh sebab itu, proyek ini juga diharapkan dapat mempertahankan ruang terbuka hijau bagi lingkungan dan masyarakat sekitar. Namun juga diharapkan mampu menciptakan lingkungan mikro pada tapak terpilih dengan nyaman, dan terciptanya lingkungan yang baik, beringin dengan konsep proyek Eco-cemetery yang mengacu pada ecology architecture. 


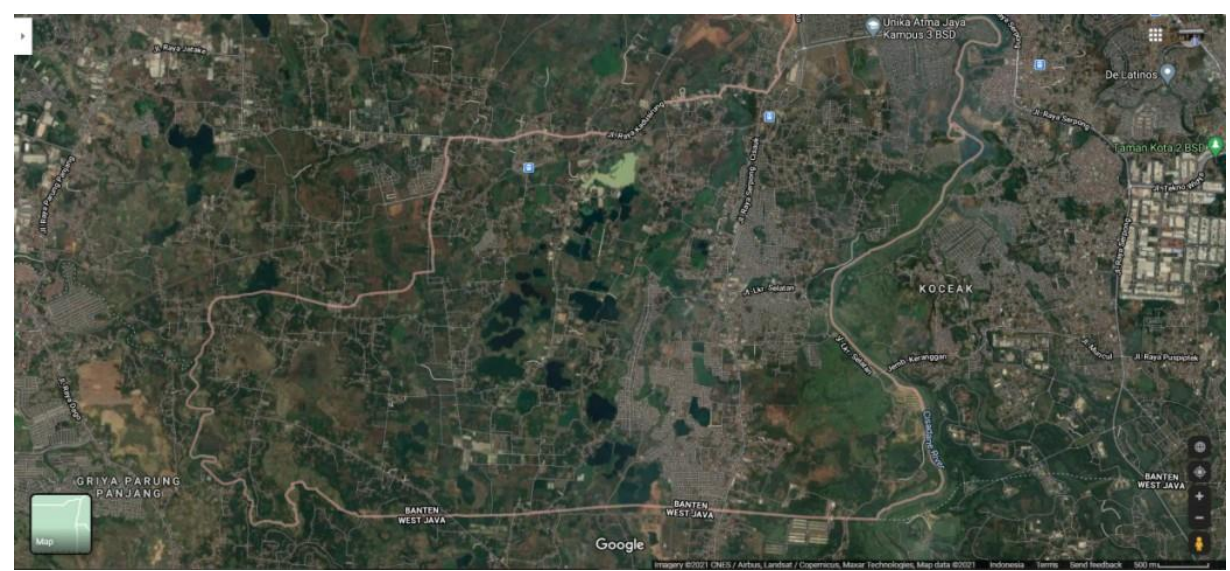

Gambar 3. Peta tapak terpilih

Sumber: www.google.com/maps

\section{Potensi dan Kendala Tapak}

Potensi Tapak Berdasarkan Kebutuhan akan Pemakaman

Tapak terpilih dapat menjadi wadah baru bagi warga sekitar yang membutuhkan ruang terbuka hijau yang baru, dan juga pemakaman yang sehat dan ekologis. Tapak dekat dengan perumahan baik perumahan menengah maupun bawah, sekolah, dan juga rumah sakit. Tetapi tidak berada di jalan utama, sehingga cocok untuk dijadikan pemakaman yang lebih cocok diletakan di tempat yang bukan titik berkumpulnya banyak orang. Di daerah sekitar KRL stasiun cisauk yang akan dijadikan kawasan TOD yang berisikan komplek apartemen dan juga perbelanjaan, memungkinkan peziarah untuk datang. Kendala tapak seperti pencapaian tapak yang tidak mudah dikarenakan akses jalan yang kecil dan berada di kawasan padat penduduk; tidak adanya transportasi umum di sekitar tapak, yang membuat pencapaian tapak lebih sulit jika adanya transportasi umum; kurangnya pengolahan dan perawatan pada ruang terbuka hijau yang saat ini tersedia; dikhawatirkan akan berkembangnya kawasan TOD Cisauk akan mengancam dan mengurangi ruang terbuka hijau di sekitar tapak.

\section{Konsep Pemakaman}

Target utama pengguna pada proyek ini yaitu masyarakat di lokasi sekitar Tangerang, yang membutuhkan pemakaman yang lebih tertata rapih, lebih ramah lingkungan dan ramah pengunjung. Target utama kedua adalah masyarat sekitar yang mebutuhkan ruang terbuka hijau yang tertata agar bisa digunakan untuk kegiatan berolah raga sehari-hari mereka. Target penunjang adalah untuk masyarakat setempat yang menjadi calon pengunjung pada proyek ini dengan kategori untuk semua kalangan masyarakat dapat menikmati hiburan pada proyek ini, dan bagi masyarakat yang datang bisa mendapatkan tempat rekreasi baru dan meningkatkan relasi sosial antar sesame. Program ruang yang disesuaikan yaitu pemakaman (yang terdiri dari makam, rumah duka, rumah abu, tempat ibadah, marketing office, foodcourt) dan ruang terbuka hijau (yang terdiri dari taman bunga, memorial statue, Jogging Track, dan toko bunga). 


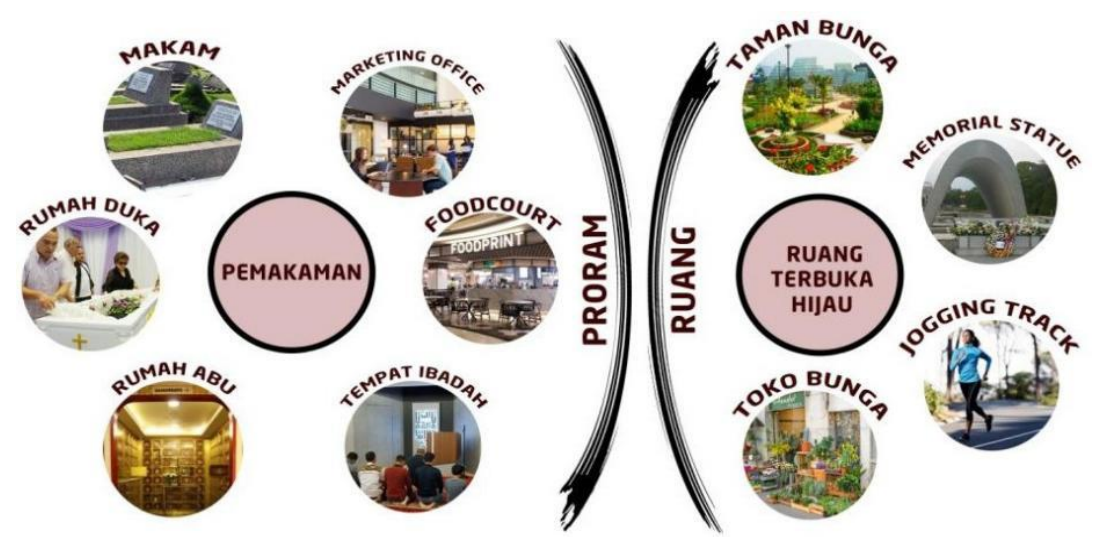

Gambar 4. Diagram Program Ruang Sumber: Penulis, 2021

\section{KESIMPULAN DAN SARAN}

\section{Kesimpulan}

Sebagaimana telah diketahui, tingkat permasalahan pemakaman di Indonesia cukup memprihatinkan baik secara efektifitas lahan maupun perawatan yang kurang baik pada sebagian besar pemakaman yang berada di kota-kota besar seperti di Kota Tangerang ini. Maka dari itu ruang terbuka hijau sangat minim untuk kebutuhan yang sesungguhnya karena ruang terbuka hijau ini digunakan untuk pembangunan pemakaman. Dengan mayoritas lanskap yang berupa ruang terbuka hijau, yang diolah dan ditata untuk mewadahi kegiatan masyarakat sekitar memilliki ruang terbuka hijau yang ramah lingkungan, aman dan nyaman untuk mereka gunakan sehari-hari, seperti adanya jogging track, jalur sepeda, taman-taman bunga yang dibantu dikelola oleh masyarakat sekitar. Dengan menerapkan metode perancangan berkonsep eco-cemetery dengan pendekatan sustainable design, diharapkan proyek ini mampu menciptakan lingkungan yang mendukung bagi manusia dan lingkungan sehingga lingkup kehidupan tetap berjalan dengan baik tanpa harus mengorbankan salah satu aspek antara lain aspek lingkungan yang dipergunakan secara tidak efisien dalam membangun pemakaman. Sebagai manusia yang memiliki akal budi dan juga ilmu disiplin lainnya seharusnya tetap memikirkan pemakaman sebagai aspek dari kehidupan bagi yang sudah meninggal.

\section{Saran}

Berdasarkan hasil penulisan jurnal "Pemakaman Masa Depan Berbasis Ramah Lingkungan" ini penulis meberikan saran untuk proyek pemakan serupa sebagai berikut, untuk lebih memperhatikan aspek-aspek ramah lingkungan, keamanan dan kenyamanan pengunjung tetapi juga keberagaman dari segi adat istiadat dan juga segi ekonomi, sehingga tidak ada perbedaan dalam pemilihan pemakaman.

\section{REFERENSI}

Curl, J. S. (2002). Death and Architecture (pp. 1, 2, 243, 253). Sutton Publishing Limited: Phoenix Mill.

Joga, N., Antar, Y. (2007). Komedi Lenong Satire Ruang Terbuka Hijau (pp. 96). Jakarta: PT. Gramedia Pustaka Utama.

John S. (1795-1863). Necropolis Glasguensis: With observation (sic) on ancient and modern tombs and sepulture (Glasgow 1831), 58,59,62.

Uslu, A. (2004) “Ecological Concerns Over Cemeteries 2009" (pp. 1509, Hakim dalam Aswad, 2004: (pp. 61, 63).

https://ggwash.org/

https://kbbi.kemdikbud.go.id/ 
https://luisdegarrido.com/research/ecological-architecture-luis-de-garrido/ https://maps.tangerangkota.go.id/ https://plato.stanford.edu/entries/ecology/\#EcoEco https://tangerangkota.bps.go.id/ http://www.bphn.go.id/data/documents/kotatangerang-2012-6.pdf https://www.nationalgeographic.org/encyclopedia/types-ecology/ 